\title{
Determinants of Bank Profitability in Western European Countries Evidence from System GMM Estimates
}

\author{
Ahlem Selma Messai ${ }^{1}$, Mohamed Imen Gallali ${ }^{1}$ \& Fathi Jouini ${ }^{2}$ \\ ${ }^{1}$ High business School of Tunis, Manouba University, Tunisia \\ ${ }^{2}$ Faculty of economics and management of Sousse, Sousse University, Tunisia \\ Correspondence: Ahlem Selma Messai, High Business School of Tunis, Manouba University, 2010 Manouba, \\ Tunisia. Tel: 216-25-16-0565. E-mail: asm_j@hotmail.fr
}

Received: April 18, 2015

Accepted: May 7, 2015

Online Published: June 25, 2015

doi:10.5539/ibr.v8n7p30

URL: http://dx.doi.org/10.5539/ibr.v8n7p30

\begin{abstract}
In this study we tried to identify the determinants of profitability for the countries of Western Europe during the distress period 2007-2011. Our sample includes 322 banks we subdivided the sample into two sub sample GIPSI countries affected by the crisis (Greece, Italy, Portugal, Spain and Ireland) and the other countries of Western Europe. We opted for several specific determinants in the bank as well as macroeconomic factors. To take account of the persistence of the benefit we used dynamic panel data (system GMM). Our results demonstrate that bank profitability depends on proxies considered and the situation of country.
\end{abstract}

Keywords: profitability, dynamic panel data, banking sector, distressed banks

\section{Introduction}

The globalization and deregulation of financial markets changed the profitability requirements and competition condition in banking system. Financial and banking market activities developed through liberalization of capital movements. Banking institutions seek to diversify activity and to have a sufficient size in order to resist to the internationalization of the market. The banking sector participates in the development of securities transactions (Rouissi, Sassi, \& Bouzgarrou, 2010).

By focusing on research carried on the banking sector in several European countries, and given the economic importance of the banking sector, it is interesting to analyze the determinants of the profitability of the banking sector based on integration of risk. It should be noted that these determinants are internal and external. Internal determinants concern financial specific characteristics to bank while external determinants are essentially macroeconomic.

During the past two decades, the banking sector underwent major transformations throughout the world in its operating environment. Both external and internal factors affected its structure and performance. Despite the rising trend in bank disintermediation in many countries, the role of banks in funding remains essential to economic activity. A soundest and profitable banking sector is able to resist adverse shocks and contribute to the stability of the financial system. Therefore, the determinants of bank's performance attracted the interest of researchers as well as bank management, financial markets and banking supervisors.

In recent decades, the banking systems of developed countries know major changes with regard their sources of income. Interest revenue were increasingly replaced by fees and commissions and trading income. According to literature, this development could lead to lower resilience of banking revenues to adverse shocks (Coffinet \& Lin, 2013). Yet many banking systems have overcame financial crisis without any failure. Some banking systems have proven to be profitable, even after the crisis.

First, profitability is the main source bank (Gropp \& Heider, 2010). Therefore, any problem with regard the profitability of banks is likely to be transmitted to solvency ratios, possibly threaten the stability of the banking system.

Second, with a collapse of the profits and difficulties in issue additional shares, banks are required to restrict lending and proceed to credit rationing to meet the regulations, and finally influence the economic growth (Van den Heuvel, 2002). 
Finally, the benefits are known as reliable early warning indicators of financial distress (Demirgüç-Kunt \& Detragiache, 1999). It is fundamental for the regulators to identify the main determinants of profits to perform accurate predictions and identify. Finally, the benefits are known as reliable early warning indicators of financial distress (Demirgüç-Kunt \& Detragiache, 1999). It is fundamental for the regulators to identify the main determinants of profits to perform accurate predictions and identify more prospectively vulnerabilities.

The study then seeks to identify the group of specific determinants of profitability for banks which involves operating efficiency and financial risks. The second group of determinants regarding the macroeconomic environment. We use GMM estimator (dynamic panel data) to seek the determinants of profitability for countries of Western Europe over the period 2007-2011. We deepen analysis dealing precisely the countries affected by the last crisis. We identify the relationship between changes in bank performance and taking risk by banking institutions.

The rest of the paper is organized as follows: the next section present a brief review of literature. Section 3 describes sample, variables and methodology. Section 4 provides analysis and result interpretation. The last section provide conclusion.

\section{Literature Review}

Previous work on the banking profitability focused on several types of determinants that are generally considered important indicators of bank profitability. Among which we can mention:

The specific variables to banks namely capital ratios, asset quality, the size of the bank and the risk borne by the financial institution (Goddard, Molyneux, \& Wilson, 2004; Kosmidou, Tanna, \& Pasiouras, 2006; Athanasoglou, Brissimis, \& Delis, 2008; Albertazzi \& Gambacorta, 2009; Lee \& Hsieh, 2013).

Macroeconomic and financial variables (GDP growth, interest rates, inflation, stock market volatility and loan growth), as established, among others, by Revell (1979), Molyneux and Thornton (1992) Demirguc-Kunt and Huizinga (2000), Beckmann (2007) Athanasoglou et al. (2008), and Albertazzi and Gambacorta (2009), Lee and Hsieh (2013).

The first works concern the banks of revenue sources focuses on net interest margins then much work has opted for the use of the financial and economic profitability. Our review of the literature describes the main works starting from Ho and Saunders (1981), and others such as Molyneux and Thornton (1992); Demirgürc-Kunt and Huizinga (1999); Saunders and Schumacher (2000); Guru, Staunton, and Shanmugam (2000); Goddard et al. (2004); Athanasoglou, Delis, and Staikouras (2006); Gelos (2009); Dietrich and Wanzenried (2011); Fungacova and Poghosyan (2011); Berger and Bouwman (2013); Lee, Hseih, and Yang (2014).

Ho and Saunders (1981), represent a framework to characterize the risk factors that influence the determination of net interest margins. This model considers the impact of the volatility of interest rates on bank interest margin. The margin based on the exposure to interest rate and institutional factors that affect the rates charged by banks on loans granted and deposits collected. According to this model, banks are assumed to be risk averse intermediaries in the financial market, collecting deposits and lending. An important factor that affects the size of the margin of the bank in this model is the transaction uncertainty due to asymmetric arrival time of the supply and demand deposits for loans. Another factor in the margin is the market structure; due to the relatively inelastic demand for loans and supply of deposits, banks choose to exercise their market power and set higher margins.

Molyneux and Thornton (1992) were the first to thoroughly explore the determinants of bank profitability on a set of countries. They use a sample of 18 European countries during the period 1986-1989. According to these authors, there is a weak and inverse relationship between liquidity and bank profitability. In order to hedge against liquidity impasses, banks are required to hold liquid assets commonly. However, these liquid assets are always associated with low rates of return. Therefore, high liquidity is associated with low profitability. These authors found a significant and positive association between the return on equity and some variables as the level of interest rates in each country, the ownership structure.

Using data specific to the bank for 80 countries in the 1988-1995 period, Demirgüç-Kunt and Huizinga (1999) analyze how the characteristics of institutions and banking environment affect interest rate margins and bank returns. The study provides a number of determining factors which affect the depositors and the behavior of the borrower, as opposed to that of shareholders. The results suggest that macroeconomic and regulatory conditions have an impact on profitability. Concentration ratios lead to lower margins and profits, while foreign ownership effect differs from industrialized and developing countries.

The study of Demirguç-Kunt and Huizinga (1999) is certainly the most important in that variables includes several factors that explain the characteristics of the bank, macroeconomic conditions, regulatory, financial 
structure and indicators legal. They show a negative correlation between profitability and reserves established by banks. Their empirical results indicate the existence of a positive relationship between the capital ratio and net interest margins. On macroeconomic variables, the authors identify a positive impact of inflation on bank margins. Also, the real interest rate is positively correlated with the profitability of banks, especially in developing countries.

Guru et al. (2000) identify the determinants of success of commercial banks to provide practical guides to improve the profitability of these institutions. The study is based on a sample of 17 banks. According to these authors, the behavior of the bank against the risk can be analyzed by the level of capital to be held by banks and liquidity management policy. In this sense, banks with high capital ratios could be considered relatively non-risky in case of loss or liquidation. However, high capital ratios present as indicators of the lower level of risk and profitability. The results of Hanweck and Ryu (2005) showed variation in interest margins are positively related to the volatility of interest rates.

Demirgüç-Kunt and Huizinga (2001) demonstrate the impact of development and financial structure on the bank's profitability by using specific data banks for a large number of developed and developing countries over the period 1990-1997. They find that financial development has a very important impact on the bank's performance. The increased competition explains the decrease in profitability. The development of the other stock markets, led to an increase in profit margins for banks especially at lower levels of financial development.

Abreu and Mendes (2003) examined the determinants of margins and profitability of the bank's interest in some European countries in the last decade. They report that well capitalized banks face lower bankruptcy costs than anticipated and this advantage implies better profitability. The amount of capital is likely to positively affect profitability, and capital can be interpreted as the amount of capital available to ensure the proper functioning of the bank, and therefore as a buffer against adverse changes in the environment macroeconomic. High capital ratio may also be considered as a signal of the high profitability of the bank.

For Goddard et al. (2004), a bank that has a relatively high proportion of capital is able to earn high profits and still at less risk. Cash and tradable securities are the most liquid assets. The holding of a high level of cash may reduce liquidity risk for banks and could help to guarantee its continuity (Berger \& Bouwman, 2013). Also Fungacova and Poghosyan (2011) find a negative relationship between the ratio of liquid assets to total assets and profitability in Russia.

Athanasoglou et al. (2006) analyze the southern European banking sector profitability over the period 1998-2002. The empirical results suggest that the improvement in bank profitability requests new risk management standards and operating efficiency. Authors apply a dynamic panel data model to study the performance of Greek banks over the period 1985 to 2001, and found some benefit of persistence, a result which indicates that the market structure is not perfectly competitive. The results also show that the profitability of Greek banks is explained by factors specific to banks and macroeconomic variables, which are not under the direct control of the bank's management. The structure of the sector does not seem to affect the profitability significantly.

Beckmann (2007) examined structural and cyclical determinants of profitability in 16 Western European countries over the period 1979-2003. The author indicates the importance of financial structure, mainly through the positive consequence of the capital market orientation in the financial system. In addition, the author demonstrates the positive effect of diversification about income sources. Regarding, business cycle impacts, measured by lagged GDP growth, shows a significant procyclical effect on bank performance. Claeys and Vennet (2008) analyze the determinants of bank in Central Europe compared to those of Western Europe in 1994-2001. These authors examine the role of specific characteristics of each banking market, macro-economic conditions in each country, the specific characteristics of banks, and regulatory characteristics to influence interest rate margins. Similarly, Gelos (2009) examines the interest rate spreads in 85 countries with a focus on Latin America. He found that higher interest rates, the efficiency of the bank and regulatory requirements contribute to higher margins in Latin America.

Dietrich and Wanzenried (2011) used GMM technique proposed by Arellano and Bover (1995) and analyzed the profitability of 372 commercial banks in Switzerland during the period from 1999 to 2009. To assess the impact of recent financial crisis, they considered separately the pre-crisis period 1999-2006, and the years of 2007-2009 crisis. The selected profitability determinants include specific features to banks as well as specific and macroeconomic factors. The authors' results show that the banks profitability is mainly due to operational efficiency, growth of total loans, and financing costs.

Fungacova and Poghosyan (2011) analyze the determinants of the interest margin in the Russian banking sector, with particular emphasis on the bank's ownership structure. By using bank-level data covering entire banking 
sector of Russia for the period 1999-2007, they found that the impact of a number of frequently used determinants such as market structure, credit risk, liquidity risk different depending on who has the ownership control (the government, national banks and the private sector and foreign companies). The results suggest that the overall form of the bank's property must be considered when analyzing the determinants of the interest margin.

Lee et al. (2014) examined the impact of income diversification on performance for a sample of 2,372 banks across 29 countries in Asia Pacific, covering the period between 1995 and 2009. Their results confirm the hypothesis that the performance of these banks can be improved through diversification.

Research also shown that macroeconomic variables can also the performance of banks. These variables reflect the economic and financial environment. These macroeconomic and financial variables usually considered are: economic growth, inflation, interest rate spread, domestic credit to the private sector.

The growth in production could have a positive impact on the profitability of banks. Indeed, higher growth can lead to higher loan distribution (increase in demand) and higher incomes indirectly on financial markets, due to higher stock market returns. In addition, with expectations of higher profits, provisions could decline during economic recovery.

Empirically, many studies show a significant and positive relationship between GDP growth and the bank's profitability. However, the effect of inflation on profitability is ambiguous and depends on whether the bank's costs are growing faster than inflation, ie, if inflation is accurately predicted by banks or not. A significantly positive effect of inflation is generally interpreted by an adjustment of interest rates and thus resulting in increasing revenues more quickly than the costs.

Saunders and Schumacher (2000) analyze the determinants of the interest margin for a sample of 6 European countries in the period 1988-1995. They find that volatility and macroeconomic regulation have a significant impact on bank interest rate margins. Their results also suggest a significant relationship between the level of capital and the net interest margin. This result shows the link between the guarantee of the solvency of banks and reduction of cost of financial services to consumers.

Several authors have opted for the growth of GDP as an explanatory variable of profitability. Among them we can cite Athanasoglou et al. (2008) and Albertazzi and Gambacorta (2009). They assume that bank profitability depends primarily on growth, independently of those countries where international groups can own assets.

Most studies on the impact of inflation on the profitability found a positive and significant relationship (Claessens, Demirguc-Kunt, \& Huizinga, 2001; Athanasoglou et al., 2006; Pasiouoras \& Kosmidou, 2007). However, Afanasieff, Lhacer, and Nakane (2002) and Naceur and Kandil (2009) found that the inflation rate adversely affects the interest margins. Naceur and Kandil (2009) explain the negative coefficient by the fact that the higher inflation rate increases uncertainty and reduces the demand for credit. This negative relationship may be related to the slower adjustment of receipts over the costs caused by inflation (Wendell \& Valderrama, 2006).

However, Perry (1992) argues that the effect of inflation on bank performance includes two cases. Firstly, If inflation is fully anticipated and interest rates are consequently adjusted. The impact of inflation on profitability will be positive. In this instance, unexpected increases in inflation cause liquidity problems for borrowers, which can lead to cancel early of loan agreements and precipitate loan losses. Secondly, if banks adjust slowly their interest rates, therefore costs are rising faster than the banks incomes.

Claeys and Vennet (2008) opted for a sample of countries in Western Europe. They found that high economic growth is associated with higher margins. A negative relationship found in the study of Demirguc-Kunt et al. (2004). Others researchers found a positive relationship between profitability and growth in real GDP (Demirguc-Kunt \& Huizinga, 1999; Bikker, \& Hu, 2002; Goddard et al., 2004; Albertazzi \& Gambacorta, 2009; Flamini et al., 2009; Davydenko, 2011; Dietrich \& Wanzenried, 2011; Zeitun, 2012). An improvement in the economic situation increases the loan request by households and businesses and improves the financial conditions of borrowers, with positive effects on the profitability of traditional financial intermediation (Albertazzi \& Gambacorta, 2009).

\section{Methodology}

\subsection{Presentation of Sample}

Our sample composed by 322 banks in Western Europe from 15 countries for the period from 2007 to 2011 . We subdivided the sample into two sub sample GIPSI countries affected by the crisis (Greece, Italy, Portugal, Spain and Ireland) and the other countries of Western Europe. 122 banks for GIPSI countries (Greece, Italy, Portugal, 
Spain and Ireland), representing 37.89\% of our overall sample. 200 banks belonging to the other 10 countries in Western Europe is $62.11 \%$ of the overall sample. Banks with missing data were eliminated from our sample. We selected only banks with available data for the entire period. The specific-bank accounting data are from the Bankscope database. We chosen only consolidated statement (code Bankscope C1, C2). About the macroeconomic data, we extracted from the World Bank (World Development Indicators).

Table 1. Presentation of the sample

\begin{tabular}{|c|c|c|c|c|c|}
\hline & & Countries & Numbers of banks & Percentage & \\
\hline \multirow{16}{*}{ Overall sample } & \multirow{5}{*}{ GIPSI countries } & Greece & 8 & $2.48 \%$ & \multirow{5}{*}{$37.89 \%$} \\
\hline & & Italy & 54 & $16.77 \%$ & \\
\hline & & Portugal & 17 & $5.28 \%$ & \\
\hline & & Spain & 34 & $10.56 \%$ & \\
\hline & & Ireland & 9 & $2.8 \%$ & \\
\hline & \multirow{11}{*}{$\begin{array}{l}\text { Others european western } \\
\text { countries }\end{array}$} & Austria & 10 & $3.11 \%$ & \multirow{10}{*}{$62.11 \%$} \\
\hline & & Belgium & 8 & $2.48 \%$ & \\
\hline & & Finland & 5 & $1.55 \%$ & \\
\hline & & France & 41 & $12.73 \%$ & \\
\hline & & Germany & 27 & $8.38 \%$ & \\
\hline & & Luxemburg & 5 & $1.55 \%$ & \\
\hline & & Netherland & 16 & $4.97 \%$ & \\
\hline & & Switzerland & 29 & $9 \%$ & \\
\hline & & Sweden & 11 & $3.42 \%$ & \\
\hline & & United kingdom & 48 & $14.91 \%$ & \\
\hline & & Total & 322 & $100 \%$ & $100 \%$ \\
\hline
\end{tabular}

\subsection{Presentation of Variables}

For variables specific to bank as determinants of performance, we selected four variables measuring capital adequacy, asset quality, liquidity.

We use three variables to approximate macroeconomic variables; inflation, the real GDP growth rate and domestic credit to the private sector. The choice of the national GDP growth and inflation rate is consistent with the choices made by Athanasoglou et al. (2008) and Albertazzi and Gambacorta (2009).

Table 2. presentation of the dependent and independent variables

\begin{tabular}{|c|c|c|c|c|}
\hline Variable & & Mesure & Notation & Expected sign \\
\hline Dependante & \multirow{2}{*}{ Profitability } & Net Interest Margin & NIM & \\
\hline \multirow[t]{5}{*}{ Variable } & & Return on average assets & ROAA & \\
\hline & Capital adequacy & Equity to total Assets & EQTA & + \\
\hline & Credit risk & Nonperforming loans to Gross loans & NPL & $+/-$ \\
\hline & Liquidity & Liquid Assets / Customer \& Short Term Funding & Liqcsf & - \\
\hline & & Net loans to total assets & Nlta & $+/-$ \\
\hline Independante & Economic growth & GDP growth rates & GDP & + \\
\hline \multirow[t]{2}{*}{ Variable } & Inflation & CPI growth rates & INF & $+/-$ \\
\hline & Domestic credit to private sector & Domestic credit to private sector(\%GDP) & DCPS & - \\
\hline
\end{tabular}




\subsection{Econometric Methods}

The methodology adopted in this work is to use a dynamic model specification with a lagged dependent variable among the explanatory variables. The presence of a delayed variable makes the conventional estimation techniques on panel data inappropriate. Thus, the use of panel data with fixed or random effects does not solve econometric problems inherent in dynamic models. This is due to the correlation between the endogenous and the residues from the regression:

$$
P R O F_{i t}=c+\delta P R O F_{i t-1}+\sum_{k=1}^{K} \beta_{k} X_{i t}^{k}+\sum_{l=1}^{L} \beta_{l} X_{i t}^{l}+\varepsilon_{i t}
$$

Where $P R O F_{i t}$ and $P R O F_{i t-1}$ are respectively the profitability levels at periods $\mathrm{t}$ and $\mathrm{t}-1$ et $\delta$ is the speed of adjustment. The error term has two components: the fixed effects, $v_{i}$ and the idiosyncratic shocks, $\mu_{i t}$.

$$
\varepsilon_{i t}=v_{i}+\mu_{i t}
$$

A value of $\delta$ between 0 and 1 implies that profits persist, but they will eventually return to their normal (average). A value close to 0 means that the industry is quite competitive (high speed adjustment), while a $\delta$ value close to 1 implies less competitive structure (very slow setting).

The dynamic panel data analysis based on the generalized method of moments (GMM). This procedure estimates, is to write the dynamic model in first differences, the use of method of instrumental variables to estimate the equation. We obtain the following expression:

$$
\triangle P R O F_{i t}=\delta \triangle P R O F_{i t-1}+\sum_{k=1}^{K} \beta_{k} \Delta X_{i t}^{k}+\sum_{l=1}^{L} \beta_{l} \Delta X_{i t}^{l}+\Delta \mu_{i t}
$$

The Sargan test is then used to test the validity of the instruments. Econometric methodology for the estimation of equations is the GMM (General Method of Moment) dynamic panel. Others standard econometric techniques such as MCO not allow to obtain efficient estimates of such a model, because of the presence of the lagged explanatory variable. The GMM provides solutions to the problems of simultaneity bias, reverse causality and omitted variables. It treats the problem of endogeneity of the variables.

There are two variants of GMM estimators: the first difference GMM estimator and system GMM estimator. The difference GMM estimator of Arellano and Bond (1991) is to take for each period the first difference of the equation in order to eliminate the specific effects by country, and instrumented explanatory variables of the first difference equation by their values lagged one period or more.

System GMM estimator proposed by Blundell and Bond (1998), combines the first difference in equations with equation at level in which the variables are instrumented by their first differences. Blundel and Bond (1998) showed with Monte Carlo simulations that the system GMM estimator is more powerful than the first difference. Difference GMM gives biased results in small samples with weak instruments.

$$
\left\{\begin{array}{c}
\triangle P R O F_{i t}=\delta \triangle P R O F_{i t-1}+\sum_{k=1}^{K} \beta_{k} \Delta X_{i t}^{k}+\sum_{l=1}^{L} \beta_{l} \Delta X_{i t}^{l}+\Delta \mu_{i t} \\
\text { PROF }_{i t}=c+\delta P R O F_{i t-1}+\sum_{k=1}^{K} \beta_{k} X_{i t}^{k}+\sum_{l=1}^{L} \beta_{l} X_{i t}^{l}+\varepsilon_{i t}
\end{array}\right.
$$

The quality of the system GMM estimators depends particularly on the validity of instruments matrix and the assumption that the no residual autocorrelation. Two tests then proposed, the first is the matrix of the instruments should not be correlated with the disturbance. This hypothesis is evaluated using the Sargan test.

Sargan test: $\mathrm{H}_{0}$. The instruments are valid.

The second is the test for residual correlation. Residual obtained from the difference equation are supposed to be correlated to first order, but not to second order. AR (1) and AR (2) test of Arellano and Bond (1991) were used to verify this hypothesis.

$\mathrm{H}_{1}$ : Negative first order correlation.

$\mathrm{H}_{0}$ : Absence of second order correlation.

\section{Results}

\subsection{Descriptive Analysis}

Descriptive statistics show that GIPSI countries have on average NIM higher than other countries in Western Europe. As against the other variable measuring profitability ROAA, have an average lower levels. The main income of the country during the period of 2007-2011 are from the intermediation activity. Banks in these countries have a minimum level of profitability of $-22,429 \%$. These countries have on average a doubtful credit higher than other European countries and have less liquid asset. On average GIPSI countries with low GDP growth rates. 
Table 3. Descriptive statistics for the dependent and independent variables

\begin{tabular}{|c|c|c|c|c|c|}
\hline Sample & Variable & Mean & Std.dev & Min & Max \\
\hline \multirow{9}{*}{ Overall sample } & NIM & 1.826427 & 1.342074 & -0.362 & 12.189 \\
\hline & ROAA & 0.3421949 & 1.461512 & -22.429 & 23.945 \\
\hline & EQTA & 7.31687 & 4.756277 & 0.003 & 60.662 \\
\hline & LIQCSF & 34.96851 & 45.83898 & 0.288 & 73.133 \\
\hline & NLTA & 60.57978 & 21.99091 & 0.101 & 98.343 \\
\hline & NPLGL & 4.705517 & 6.408926 & 0 & 69.56 \\
\hline & INF & 2.061749 & 1.408903 & -4.48 & 12.68 \\
\hline & DCPS & 151.8686 & 43.8093 & 81.5231 & 261.3887 \\
\hline & GDP & 0.4319429 & 2.718646 & -8.54 & 6.64 \\
\hline \multirow{9}{*}{$\begin{array}{c}\text { GIPSI } \\
\text { Countries }\end{array}$} & NIM & 2.113916 & .9993646 & 0.143 & 12.189 \\
\hline & ROAA & 0.1165541 & 1.914014 & -22.429 & 5.003 \\
\hline & EQTA & 7.766744 & 4.498509 & 0.003 & 60.662 \\
\hline & LIQCSF & 25.17463 & 44.83899 & 0.759 & 651.592 \\
\hline & NLTA & 66.9117 & 18.19817 & 0.101 & 98.343 \\
\hline & NPLGL & 6.53912 & 7.527767 & 0 & 62.373 \\
\hline & INF & 2.122623 & 1.578389 & -4.48 & 4.88 \\
\hline & DCPS & 154.491 & 46.02564 & 94.0559 & 234.535 \\
\hline & GDP & -0.3628525 & 2.702078 & -6.91 & 5.45 \\
\hline \multirow{9}{*}{$\begin{array}{l}\text { Others western } \\
\text { european } \\
\text { countries }\end{array}$} & NIM & 1.672596 & 1.470999 & -.362 & 11.873 \\
\hline & ROAA & 0.4629325 & 1.131082 & -9.106 & 23.945 \\
\hline & EQTA & 7.076147 & 4.873517 & 0.246 & 52.661 \\
\hline & LIQCSF & 40.2091 & 45.52671 & 0.288 & 732.133 \\
\hline & NLTA & 57.19165 & 23.07731 & 1.205 & 97.438 \\
\hline & NPLGL & 3.724378 & 5.478055 & 0.013 & 69.56 \\
\hline & INF & 2.029175 & 1.308813 & -0.49 & 12.68 \\
\hline & DCPS & 150.2689 & 42.34434 & 81.5231 & 261.389 \\
\hline & GDP & 0.8572281 & 2.631769 & -8.54 & 6.64 \\
\hline
\end{tabular}

The absence of multicollinearity is a necessary condition for the estimation in regression. The correlation matrix shows the absence of a strong correlation between the explanatory variables in the model. This level is below the threshold set in the literature.

Table 4. Pearson correlation matrix

\begin{tabular}{|c|c|c|c|c|c|c|c|}
\hline & EQTA & LIQCSF & NLTA & NPLGL & INF & DCPS & GDP \\
\hline EQTA & 1.0000 & & & & & & \\
\hline LIQCSF & -0.0286 & 1.0000 & & & & & \\
\hline NLTA & 0.0231 & $-0.5443^{* * *}$ & 1.0000 & & & & \\
\hline NPLGL & $0.1554^{* * *}$ & -0.0355 & $0.0161^{*}$ & 1.0000 & & & \\
\hline INF & -0.0387 & $-0.0499^{* *}$ & $0.0513^{* *}$ & $0.1312^{* * * *}$ & 1.0000 & & \\
\hline DCPS & $0.0485^{*}$ & -0.0294 & $0.0849^{* * * *}$ & $-0.0861^{* * *}$ & $0.0424^{*}$ & 1.0000 & \\
\hline GDP & -0.0088 & 0.0258 & $-0.0571^{* *}$ & $-0.0673^{* * *}$ & $0.2670^{* * *}$ & $-0.0421^{*}$ & 1.0000 \\
\hline
\end{tabular}

Note. $\left({ }^{* * *}\right),\left(^{* *}\right)$ et $\left(^{*}\right)$ significant respectively at $1 \%, 5 \%$ et $10 \%$. 


\subsection{Dynamic Panel Data Analysis}

The result of the application of dynamic panel method will be presented by group of countries and proxies of bank profitability. We validated instruments using the Sargan test. Similarly, we verified the absence of the autoregressive process of order 2 for all estimates (see Table 5).

In the case where profitability is approximated by NIM and for the overall sample, profitability is explained by the rate of inflation GDP growth rate, delayed variable NIM and the ratio of total net loans assets. About the GIPSI countries, in addition to these variables, profitability is affected by the ratio of capital and liquidity ratio. Our results show that the lagged $\mathrm{NIM}_{\mathrm{t}-1}$ variable is significant at $1 \%$ it asserts the dynamic nature of the model. Our results also demonstrate that the capital ratio has a positive effect on bank profitability. It is significant for two subsamples. Indeed, well-capitalized banks need to borrow less to support a given level of assets, and tend to deal with the cost of financing.

Table 5. Dynamic panel data estimation result

\begin{tabular}{|c|c|c|c|c|c|c|}
\hline \multirow[t]{2}{*}{ Variables } & \multicolumn{3}{|c|}{ NIM } & \multicolumn{3}{|c|}{ ROAA } \\
\hline & Overall & Others & Gipsi & overall & others & Gipsi \\
\hline \multirow[t]{2}{*}{$\mathrm{NIM}_{\mathrm{t}-1}$} & $0.5854151^{* * *}$ & $0.8577708^{* * * *}$ & $0.2991679^{* *}$ & & & \\
\hline & $(3.72)$ & (10.99) & $(2.66)$ & & & \\
\hline \multirow[t]{2}{*}{$\operatorname{ROAA}_{t-1}$} & & & & $0.5878977^{* * * *}$ & $0.475211^{*}$ & $0.2388076^{* * * *}$ \\
\hline & & & & $(4.29)$ & $(1.82)$ & $(2.94)$ \\
\hline \multirow[t]{2}{*}{ EQTA } & 0.0431994 & $0.0230642^{* *}$ & $0.1410222^{* * *}$ & $0.1422098^{* *}$ & -0.0394718 & $0.1654014^{* *}$ \\
\hline & $(1.40)$ & $(2.13)$ & $(3.41)$ & $(2.02)$ & $(-0.31)$ & $(2.34)$ \\
\hline \multirow[t]{2}{*}{ LIQCSF } & -0.0082075 & 0.0012803 & $-0.0207352^{* *}$ & 0.0040643 & $-0.0265308^{* * *}$ & $-0.0345446^{* * *}$ \\
\hline & $(-1.25)$ & $(0.28)$ & $(-2.15)$ & $(0.54)$ & $(-2.90)$ & $(-3.38)$ \\
\hline \multirow[t]{2}{*}{ NLTA } & $0.0488186^{*}$ & -0.0006125 & $0.0553121^{* * *}$ & -0.0222909 & 0.0051013 & $-0.0663035^{* * * *}$ \\
\hline & (1.66) & $(-0.07)$ & $(2.79)$ & $(-0.55)$ & $(0.23)$ & $(-2.93)$ \\
\hline \multirow[t]{2}{*}{ NPLGL } & 0.0003951 & $0.0227754^{*}$ & -0.0053121 & $-0.1499079^{* * *}$ & -0.0318498 & $-0.2757522^{* * *}$ \\
\hline & $(0.02)$ & (1.74) & $(-0.41)$ & $(-4.26)$ & $(-0.88)$ & $(-12.60)$ \\
\hline \multirow[t]{2}{*}{ INF } & $-0.0835635^{* * *}$ & $-0.0698935^{* * *}$ & $-0.1365198^{* * *}$ & 0.0688478 & 0.0804599 & $0.0770848^{* *}$ \\
\hline & $(-2.91)$ & $(-3.34)$ & $(-4.76)$ & $(1.30)$ & $(0.92)$ & $(2.26)$ \\
\hline \multirow[t]{2}{*}{ DCDP } & -0.0017169 & 0.0019759 & -0.0036751 & $0.0088638^{* * *}$ & -0.0063013 & 0.0030228 \\
\hline & $(-0.68)$ & $(1.31)$ & $(-1.16)$ & $(2.71)$ & $(-1.58)$ & $(1.05)$ \\
\hline \multirow[t]{2}{*}{ GDP } & $0.0314462^{* *}$ & $0.0365037^{* * *}$ & $0.081554^{* * *}$ & 0.0009188 & 0.036916 & $-0.0670764^{* * *}$ \\
\hline & $(2.14)$ & $(3.85)$ & (4.16) & $(0,03)$ & $(0.96)$ & $(-2.90)$ \\
\hline \multirow[t]{2}{*}{ _cons } & -1.676392 & -0.1961959 & -1.673772 & -0.4157517 & 1.996166 & $5.205586^{* * *}$ \\
\hline & $(-1.01)$ & $(-0.42)$ & $(-1.06)$ & $(-0.16)$ & $(1.34)$ & $(3.20)$ \\
\hline Fisher & 22.57 & 99.17 & 25.16 & & & \\
\hline Chi2(8) & & & & 332.99 & 69.70 & 784.03 \\
\hline $\mathrm{AR}(1)$ & -3.33 & -3.18 & -2.32 & -7.24 & -2.47 & -2.99 \\
\hline Pvalue & 0.001 & 0.001 & 0.020 & 0.000 & 0.014 & 0.003 \\
\hline $\mathrm{AR}(2)$ & 0.24 & -0.56 & 0.46 & -1.42 & 1.63 & -0.10 \\
\hline Pvalue & 0.809 & 0.573 & 0.647 & 0.155 & 0.103 & 0.917 \\
\hline Sargan test & 0.65 & 3.51 & 4.88 & 7.07 & 4.39 & 6.92 \\
\hline Pvalue & 0.957 & 0.476 & 0.300 & 0.314 & 0.734 & 0.328 \\
\hline Hansen test & 2.28 & 2.88 & 3.02 & & & \\
\hline Pvalue & 0.685 & 0.578 & 0.555 & & & \\
\hline
\end{tabular}

Note. $\left({ }^{* * *}\right),\left(^{* *}\right)$ et $\left({ }^{*}\right)$ significant respectively at $1 \%, 5 \%$ et $10 \%$. The value in parentheses denotes the $\mathrm{t}$-student. 
The positive relationship can be explained by the presence of a positive causality between profit and capital. This is achieved when the profits are reinvested fully or partially. Similarly, the total assets to capital ratio are used as an indicator of risk aversion of the bank (Maudos \& Guevara, 2004). As capital is more expensive than deposits, a higher proportion of equity in total assets indicates a greater risk aversion.

Equity as a source of funds more expensive than deposits, increased equity may increase the cost of capital of the bank which is required to establish a higher margin. Increasing the pressure on banks to reduce costs encourages them to engage in riskier and also generating activities of the largest profitability.

We found a positive and significant effect of the capital ratio on bank profitability. Our results confirm those found by then Athanasoglou et al. (2006).

Our results also show that the impact of credit risk as measured by non-performing loans is not significant on the profitability of banks measured by NIM for GIPSI country.

However, the effect is positive and significant only at $10 \%$ for the other countries in the region. Banks with higher ratios of nonperforming loans are confronted with a higher risk of credit. This result can be explained by portfolio theory and linear and positive relationship between return and risk. To achieve a high yield, take more risk. This ratio is an indicator of the quality of assets generating interest, since the banks whose loans are more risky, are forced to demand higher interest margin to compensate for a higher risk of default.

The impact of net loans to total assets ratio (NLTA) is significant and positive and in accordance with our expectations.

Net loans to total assets ratio used to indicate asset quality form many studies, as a measure of the bank's credit risk. This is consistent with standard asset pricing arguments that imply a positive relationship between risk and profit. Empirical studies find that higher loan ratio is associated with higher interest margins, which suggest that the risk averse shareholders seeking greater gains to offset the high credit risk (Demirguc-Kunt \& Huizingua, 1999; Flamini et al., 2009). Lee and Hsieh (2013) also find that the coefficients of the ratio of net loans to total assets are significantly positive on profititabilité (ROA and ROE) for 42 Asian countries.

Interest margins are higher for banks with a higher ratio of net loans to assets. This indicates that banks grant loans for riskier projects require higher margins than the compensation (Maudos et al., 2004). The liquidity ratio is only significant for GIPSI countries where profitability is approximated by NIM and for the two sub sample when profitability is measured by ROAA. The relationship between the liquidity ratio (LCSTF) and bank profitability is negative. This result confirms those found by Molyneux and Thornton (1992), Guru et al. (2000), Pasiouras and Kosmidou (2007) and Rouissi et al. (2010).

Banking Performance should be sensitive to macroeconomic variables. We found that the GDP growth rate as an indicator of cyclical effects of the production has a positive influence on bank profitability. This result is significant when profitability is measured by the net interest margin for the two sub samples. Indeed, the reduction and low GDP growth in a recession always causes a decrease in credit quality and consequently a reduction in bank profitability.

When profitability is approximated by the NIM, we found that the inflation rate is negatively on profitability. This result is significant at a level of $1 \%$. This result is similar to those of Afanasieff et al. (2002) and Naceur and Kandil (2009) who found that the rate of inflation adversely affects the interest margins. This negative relationship between inflation and profitability can be explained by the fact that a higher rate of inflation increases uncertainty and reduces the demand for credit (Naceur \& Kandil, 2009). We could also argue that this negative relationship may be related to the slowest adjustment of revenue over costs of inflation (Wendell \& Valderrama, 2006).

Unexpected increases in inflation cause liquidity problems for borrowers, which can lead to premature termination of the loan agreements and precipitate loan losses. Indeed, if banks slowly adjust their interest rates, there is a possibility that the bank costs may rise faster than income of banks (Perry, 1992). Our result is contrary to that obtained by Horvath (2009).

In the case where profitability is approximated by the ROAA and for the overall sample, profitability is explained by domestic credit to the private sector, the lagged variable of ROAA, capital ratio and credit risk as measured by loans non-performing.

As for GIPSI countries, all variables are significant except domestic credit index for private sector, we also notice a change of sign for macroeconomic variables and for the ratio of net loans to total assets.

The significance of lagged variable coefficient ROAt- 1 for banks at $1 \%$ confirms the dynamic nature of the 
model.

As with the first proxy, we found the same result by taking the ROAA as the dependent variable. The coefficient of the variable capital adequacy (capital adequacy) EQTA is positive and highly significant (significance at 1\%). The positive sign of EQTA coefficient was found in most of the works that dealt with bank profitability ie Demirguc-Kunt and Huizinga (1999, 2000), Claessens et al. (2001), Goddard et al. (2004) and Athanasoglou et al. (2008).

We also found that the risk of credit (NPLGL) acts negatively on profitability approximated by the ROAA. This result indicates that higher the risk, higher the probability to have bad debts important. Indeed, to a lender, the loss of loan capital is on outstanding amounts that are directly binding on the result and imperil the bank's sustainability and contuinity.

This result is similar to that obtained by Williams (2007), which reports a negative association between credit risk and profitability of Australian banks. The negative sign could also imply that these banks do not have the appropriate tools for the control of credit risk when creating their margins. It could also indicate a more aggressive strategy from the banks seeking to have a significant market share and thus they are prepared to accept a higher credit risk without increasing their margins.

For GIPSI country, agents who received credit, they have difficulty to deal with their commitments. The increase in loans also leads to an increase in non-performing loans. In this case, the relationship between credit risk and profitability depends on the countries in Western Europe. Similarly, for the inflation rate and GDP growth rate.

Indeed, for GIPSI countries, we found a positive relationship between inflation and profitability approximated by ROAA. Most studies on the impacts of inflation on the profitability found a positive and significant relationship (Claessens et al., 2001; Athanasoglou et al., 2006, Pasiouoras \& Kosmidou, 2007; Athanasoglou et al., 2008; Albertazzi \& Gambacorta, 2009).

In general, high inflation rates are associated with high loan interest rates and thus a high income. Our result is in contrast to that of Horvath (2009) who found that banks determine higher margins when there are more price inflation. Thus, central banks seek to achieve price stability also contributes to a better financial intermediation (Boyd et al., 2001), which is crucial to the economic and financial development.

\section{Conclusion}

This research tries to detect the determinants of profitability for the countries of Western Europe during the 2007-2011 period of distress in a sample of 322 banks. We divided the sample into two groups GIPSI countries affected by the crisis (Greece, Italy, Portugal, Spain and Ireland) and the other countries of Western Europe. In this study, we opted for several specific determinants in the bank and other macroeconomic factors. the econometric technique used is the dynamic panel (system GMM estimator). Our results demonstrate that bank profitability depends on country category so far considered. Our result shows that the capital ratio and the credit risk are the most relevant determinants of bank profitability. The estimation is done twice: For the first estimate profitability is approximated by the NIM and the second estimate by using the ROAA; the most relevant variables: inflation rate, GDP growth rate, and the ratio net loans/total assets. Profitability and the ratio net loans/total assets associated positively as a high level of loans is associated with higher interest margins and thus systematically to higher profitability. Inflation negatively affects interest margins and unexpected increases in price indices cause liquidity problems for borrowers which in turn leads to the sudden stop lending and increasing volume of non-performing loans. The GDP growth rate positively affects bank profitability since it directly affects the incomes of businesses and households. Which enhances economic stability and bank profitability. This study demonstrates the effect of specific and macroeconomic variables on banking institution profitability. Banks must take an interest and monitoring these variables to improve performance especially variables on the quality of assets, adequacy of capital and liquidity. Banking institutions should diversify sources of revenues and seek to optimize costs. The regulations institutions should establish a better supervision for credit and liquidity risk and encourage banking competition.

This research could be improved if we had to add other variables inherent in bank governance in order to enhance the robustness of the model. The importance of the financial sector in the economy and development of the country, encourages us to add other variables concerning the specificity of countries. We can also extend the work by including developing countries. We can decompose countries according to their performance (countries with high performance and low performing countries) as the ranking given by the World Bank.

\section{References}

Abreu, M., \& Mendes, V. (2003). Do macro-financial variables matter for European bank interest margins and 
profitability? Retrieved from http://www.repository.utl.pt/bitstream/10400.5/1365/1/MA-EcoMod2003.pdf

Afanasieff, T., Lhacer, P., \& Nakane, M. (2002). The determinants of bank interest spreads in Brazil. Working Paper, Banco Central di Brazil. Retrieved from http://www.bcb.gov.br/ingles/public/wps/wps46.pdf

Agusman, A., Monroe, G. S., Gasbarro, D., \& Zumwalt, J. K. (2008). Accounting and capital market measures of risk: Evidence from Asian banks during 1998-2003. Journal of Banking and Finance, 32(4), 480-488. http://dx.doi.org/10.1016/j.jbankfin.2006.06.018

Albertazzi, U., \& Gambacorta, L. (2009). Bank profitability and the business cycle. Journal of Financial Stability, 5(4), 393-409. http://dx.doi.org/10.1016/j.jfs.2008.10.002

Angbazo, L. (1997). Commercial banks, net interest margins, default risk, interest rate risk and off-balance sheet banking. Journal of Banking and Finance, 21(1), 55-87. http://dx.doi.org/10.1016/S0378-4266(96)00025-8

Arellano, M., \& Bond, S. R. (1991). Some tests of specification for panel data: Monte Carlo evidence and an application to employment equations. Review of Economic Studies, 58(2), 277-297. http://dx.doi.org/10.2307/2297968

Athanasoglou, P. P., Brissimis, S. N., \& Delis, M. (2008). Bank specific, industry specific and macroeconomic determinants of bank profitability. Journal of International Financial Markets, Institutions and Money, 18(2), 121-136. http://dx.doi.org/10.1016/j.intfin.2006.07.001

Athanasoglou, P., Delis, M., \& Staikouras, C. (2006). Determinants of banking profitability in the South Eastern European Region. Bank of Greece, wp 06/47. Retrieved from http://www.bankofgreece.gr/BogEkdoseis/Paper200647.pdf

Beckmann, R. (2007). Profitability of Western European banking systems: Panel evidence on structural and cyclical determinants. Discussion Paper Series 2: Banking and Financial Studies, 17. Deutsche Bundesbank, Research Centre. http://dx.doi.org/10.2139/ssrn.1090570

Bejaoui, R., Sassi, S., \& Bouzgarou, H. (2010). L'analyse des déterminants de la rentabilité des banques françaises Comparaison entre banques domestiques et banques étrangères. $3^{\text {rd }}$ Euro African Conference in Finance and Economics. Retrieved from http://www.tn.refer.org/CEAFE/Papiers_CEAFE10/Eco_bancaire/BejaouiRouissi.pdf

Berger, A. N., \& Bouwman, C. H. S. (2013). How does capital affect bank performance during financial crises? Journal of Financial Economics, 109(1), 146-176. http://dx.doi.org/10.1016/j.jfineco.2013.02.008

Bikker, J., \& Hu, H. (2002). Cyclical patterns in profits, provisioning and lending of banks and procyclicality of the new Basel capital requirements. BNL Quarterly Review, 221, 143-175. Retrieved from http://www.dnb.nl/en/binaries/ot039_tcm47-146052.pdf

Blundell, R., \& Bond, S. (1998). Initial conditions and moment restrictions in dynamic panel data models. Journal of Econometrics, 87(1), 115-143. http://dx.doi.org/10.1016/S0304-4076(98)00009-8

Boyd, J. H., Levine, R., \& Smith, B. D. (2001). The impact of inflation of financial sector performance. Journal of Monetary Economics, 47(2), 221-248. http://dx.doi.org/10.1016/S0304-3932(01)00049-6

Claessens, S., Demirgüç-Kunt, A., \& Huizinga, H. (2001). How does foreign entry affect the domestic banking markets? Journal of Banking and Finance, 25(5), 891-911. http://dx.doi.org/10.1016/S0378-4266(00)00102-3

Claeys, S., \& Vennet, R. (2008). Determinants of bank interest margins in Central and Eastern Europe: A $\begin{array}{lllll}\text { comparison with the West. Economic Systems, 32(2), 197-216. } & \text {. }\end{array}$ http://dx.doi.org/10.1016/j.ecosys.2007.04.001

Davydenko, A. (2011). Determinants of bank profitability in Ukraine. Undergraduate Economic Review, 7(1), 1-30. Retrieved from http://digitalcommons.iwu.edu/uer/vol7/iss1/2

Demirgüç-Kunt, A., \& Huizinga, H. (1999). Determinants of commercial bank interest margins and profitability: Some international evidence. World Bank Economic Review, 14(2), 379-408. http://dx.doi.org/10.1596/1813-9450-1900

Demirguc-Kunt, A., \& Huizinga, H. (2001). Financial structure and bank profitability. World Bank Economic Review. http://dx.doi.org/10.1596/1813-9450-2430

Demirguc-Kunt, A., Laeven, L., \& Levine, R. (2004). Regulations, market structure, institutions, and the cost of financial intermediation. Journal of Money, Credit and Banking, 36, 593-622. 
http://dx.doi.org/10.1353/mcb.2004.0045

Dietrich, A., \& Wanzenried, G. (2011). Determinants of bank profitability before and during the crisis: Evidence from Switzerland. Journal of International Financial Markets, Institutions and Money, 21(3), 307-327. http://dx.doi.org/10.1016/j.intfin.2010.11.002

Flamini, V., McDonald, C., \& Schumacher, L. (2009). The determinants of commercial bank profitability in subSaharan Africa. IMF Working Paper 09/15. http://dx.doi.org/10.5089/9781451871623.001

Fungacova, Z., \& Poghosyan, T. (2011). Determinants of bank interest margins in Russia: Does bank ownership matter? Economic Systems, 35, 481-495. http://dx.doi.org/10.1016/j.ecosys.2010.11.007

Gelos, G. R. (2009). Banking spreads in Latin America. Economic Inquiry, 47(4), 796-814. http://dx.doi.org/10.1111/j.1465-7295.2008.00144.x

Goddard, J., Molyneux, P., \& Wilson, J. O. S. (2004). Dynamics of growth and profitability. Banking, Journal of Money, Credit and Banking, 36, 1069-1090. http://dx.doi.org/10.1111/j.1467-9957.2004.00397.x

Gropp, R., \& Heider, F. (2010). The determinants of bank capital structure. Review of Finance, 4(4), 587-622. http://dx.doi.org/10.1093/rof/rfp030

Guru, B., Staunton, J., \& Shanmugam, B. (2000). Determinants of commercial bank profitability in Malaysia. Asian Academy of Management Journal. Retrieved from http://web.usm.my/aamj/5.2.2000/5-2-1.pdf

Ho, T., \& Saunders, A. (1981). The determinants of bank interest margins: Theory and empirical evidence. Journal of Financial and Quantitative Analysis, 16(4), 581-600. http://dx.doi.org/10.2307/2330377

Horvath, R. (2009). The determinants of the interest rate margins of Czech Banks. Czech Journal of Economics and Finance, 59(2), 128-136. Retrieved from http://journal.fsv.cuni.cz/storage/1154_1154_horvath.pdf

Kosmidou, K. (2008). The determinants of banks' profits in Greece during the period of EU financial integration. Managerial Finance, 34(3), 146-159. http://dx.doi.org/10.1108/03074350810848036

Kosmidou, K., Tanna, S., \& Pasiouras, F. (2006). Determinants of profitability of domestic UK commercial bank: Panel evidence from the period 1995-2002. Economics, Finance and Accounting Applied Research Working Paper. Retrieved from https://curve.coventry.ac.uk/open/file/0e96868ac91f 7854 ffc7 b1d58eb809ed/1/Determinants\%20of\%20pro fitability.pdf

Lee, C. C., \& Hsieh, M. F. (2013). The impact of bank capital on profitability and risk in Asian Banking. Journal of International Money and Finance, 32, 251-281. http://dx.doi.org/10.1016/j.jimonfin.2012.04.013

Lee, C. C., Hsieh, M. F., \& Yang, S. J. (2014). The relationship between revenue diversification and bank performance: Do financial structures and financial reforms matter? Japan and the World Economy, 29, 18-35. http://dx.doi.org/10.1016/j.japwor.2013.11.002

Maudos, J., \& Guevara, J. F. (2004). Factors Explaining the Interest Margin in the Banking Sectors of the European Union. Journal of Banking and Finance, 28(9), 2259-2281. http://dx.doi.org/10.1016/j.jbankfin.2003.09.004

Molyneux, P., \& Thorton, J. (1992). Determinants of European bank profitability: A note. Journal of Banking and Finance, 16(6), 1173-1178. http://dx.doi.org/10.1016/0378-4266(92)90065-8

Naceur, S., \& Kandil, M. (2009). The impact of capital requirements on banks' cost of intermediation and performance: The case of Egypt. Journal of Economics and Business, 61, 70-89. http://dx.doi.org/10.1016/j.jeconbus.2007.12.001

Pasiouras, F., \& Kosmidou, K. (2007). Factors influencing the profitability of domestic and foreign commercial banks in the European Union. Research in International Business and Finance, 21, 222-237. http://dx.doi.org/10.1016/j.ribaf.2006.03.007

Perry, P. (1992). Do banks gain or lose from inflation. Journal of Retail Banking, 14(2), 25-30.

Revell, J. (1979). Inflation and financial institutions. The Financial Times Ltd., London.

Saunders, A., \& Schumacher, L. (2000). The determinants of bank interest rate margins: An international study. Journal of International Money and Finance, 19(6), 813-832. http://dx.doi.org/10.1016/S0261-5606(00)00033-4

Van den Heuvel, S. J. (2002). Does bank capital matter for monetary transmission? FRBNY Economic Policy 
Review, 259-265. Retrieved from http://www.newyorkfed.org/research/epr/02v08n1/0205vand.pdf

Wendell, S., \& Valderrama, L. (2006). The monetary policy regime and banking spreads in Barbados. IMF working papers, WP/06/211. Retrieved from https://www.imf.org/external/pubs/ft/wp/2006/wp06211.pdf

Williams, B. (2007). Factors determining net interest margins in Australia: Domestic and foreign banks. Financial Markets, Institutions and Instruments, 16, 145-165. http://dx.doi.org/10.1111/j.1468-0416.2007.00122.x

Zarruk, R. E. (1989). Bank spread with uncertaintly deposit level and risk aversion. Journal of Banking and Finance, 13, 797-810. http://dx.doi.org/10.1016/0378-4266(89)90002-2

Zeitun, R. (2012). Determinants of Islamic and Conventional Banks performance in GCC countries using panel data analysis. Global Economy and Finance Journal, 5(1), 53-72. Retrieved from http://www.gefjpapers.com/static/documents/March/2012/4.\%20Rami.pdf

\section{Copyrights}

Copyright for this article is retained by the author(s), with first publication rights granted to the journal.

This is an open-access article distributed under the terms and conditions of the Creative Commons Attribution license (http://creativecommons.org/licenses/by/3.0/). 